Bartosz Michalski*

\title{
W POSZUKIWANIU DYWERSYFIKACJI. STAN I PERSPEKTYWY ROZWOJU POLSKO- -SKANDYNAWSKIEJ WYMIANY HANDLOWEJ
}

\section{Wprowadzenie}

Harmonijny rozwój stosunków handlowych stanowi jedno z najważniejszych zadań w ramach zagranicznej polityki ekonomicznej. Jednocześnie trwałość istniejących relacji oddziałuje na zasadzie sprzężenia zwrotnego na jakość więzi dyplomatycznych, a co za tym idzie możliwość wspólnego określania priorytetów politycznych. Istotną kwestią jest zapewnienie sobie możliwie jak największego pola manewru decyzyjnego, co wymaga posiadania odpowiednio zdywersyfikowanej sieci dwuoraz wielostronnych kontaktów.

Ofensywa polskiej dyplomacji ukierunkowana na odbudowanie zaufania w ramach Grupy Wyszehradzkiej, jakkolwiek zrozumiała z punktu widzenia geopolitycznych interesów (kolektywne bezpieczeństwo w Europie Środkowej), natrafia także na krytykę wskazującą konieczność większego docenienia współpracy z krajami skandynawskimi (koncepcja tzw. Trójmorza). Czechy, Słowacja oraz Węgry zostały wręcz skolonizowane gospodarczo przez kapitał zagraniczny (głównie niemiecki) i jako takie nie są atrakcyjnymi partnerami dla Polski, także stojącej przed wyzwaniem zrzucenia (ograniczenia) zależności ${ }^{1}$. Konieczne staje się zatem zdefiniowanie możliwości rozwojowych, innych niż kompleksowa współpraca z Niemcami, poprzez poszukiwanie nowych rynków oraz partnerów gospodarczych w wymiarze transbałtyckim.

Powyższe stało się motywacją dla przyjęcia za cel badania oceny perspektyw rozwoju współpracy handlowej Polski z Danią, Finlandią, Norwegią oraz Szwecją. Przeprowadzona analiza ewolucji dotychczasowych stosunków została skoncentrowana na wymiarze mezo- i mikroekonomicznym. Jednocześnie jej szerszy kontekst

* Wydział Nauk Społecznych, Uniwersytet Wrocławski.

1 P. Wójcik, Mit Wyszehradu. Niedoceniony Bałtyk, „Dziennik Gazeta Prawna” nr 92/4239, 13-15 maja 2016, s. A27. 
stanowi problematyka bezpieczeństwa ekonomicznego Polski, rozumianego tutaj jako względnie zrównoważony endo- i egzogennie stan funkcjonowania gospodarki narodowej, w którym występujące ryzyko zaburzeń równowagi utrzymane jest w wyznaczonych i akceptowalnych normach organizacyjno-prawnych oraz zasadach współżycia społecznego ${ }^{2}$. Ponadto bezpieczeństwo ekonomiczne jest definiowane na cztery sposoby: odnosi się do zagrożeń, łączy refleksję nad zagrożeniami i możliwościami, odwołuje się do zdolności państwa do funkcjonowania oraz ujmuje specyfikę konkretnego przypadku³.

W wymiarze praktycznym przekłada się to na wymóg systematycznego rozwijania materii studiów strategicznych. Obejmuje ona swoim zakresem merytorycznym m.in. refleksję nad stanem polskiego bezpieczeństwa ekonomicznego, odnoszącym się do jakości relacji gospodarczych z zagranicą oraz przełożenia na sytuację wewnętrzną, m.in. poprzez rozwój polskich firm eksportowych, konkurencję importową, napływ inwestycji zagranicznych, transfer technologii, wsparcie innowacyjności czy funkcjonowanie rynków pracy.

\section{Uwagi metodologiczne}

Podjęta $\mathrm{w}$ artykule problematyka ściśle wiąże się z ujęciem dyskursywnym, wpisywanym w nurt rozważań związanych z ekonomią polityczną stosunków międzynarodowych ${ }^{4}$, w tym przypadku w jej strukturalistyczno-konstruktywistycznym ujęcius.

Nie mniej istotny jest także postulat (od) budowy kultury strategicznej ${ }^{6}$, rozumianej jako zdolność - uwarunkowana wewnętrznym i zewnętrznym kontekstem historycznym, politycznym czy społecznym - do identyfikowania zagrożeń dla bezpieczeństwa, określania i konsekwentnego urzeczywistniania długofalowych celów. Jest

2 K. Raczkowski, Percepcja bezpieczeństwa ekonomicznego i wyzwania dla zarzadzania nim w XXI wieku, [w:] Bezpieczeństwo ekonomiczne. Wyzwania dla zarządzania państwem, red. K. Raczkowski, Oficyna a Wolter Kluwers business, Warszawa 2012, s. 81.

3 Zob. szerzej K. Księżopolski, Bezpieczeństwo ekonomiczne, Dom Wydawniczy Elipsa, Warszawa 2011, s. $27-28$ i n.

4 Zob. i por. ibidem, s. 30.

5 Zob. szerzej R. Smith, I. El-Anis, C. Farrands, International Political Economy in the 21st Century. Contemporary Issues and Analyses, Routledge, New York 2013, s. 33-45 oraz T.H. Cohn, Global Political Economy. Theory and Practice, Routledge, New York 2016, s. 114-116.

6 Zob. szerzej i por. K. Malinowski, Kultura bezpieczeństwa narodowego: koncepcja i możliwości zastosowania, [w:] Kultura bezpieczeństwa narodowego w Polsce i Niemczech, red. K. Malinowski, Instytut Zachodni, Poznań 2003 oraz R. Wiśniewski, Kultura strategiczna, czyli o kulturowych uwarunkowaniach polityki zagranicznej i bezpieczeństwa, „Przegląd Strategiczny” nr 1, 2012. 
ona niezbędna dla przezwyciężania dryfu rozwojowego w ramach członkostwa w Unii Europejskiej i zbyt silnego uzależnienia polskiej gospodarki od współpracy z Niemcami (zob. dalej autorska teza dotycząca klątwy niemieckiej bliskości geograficznej).

W badaniu wykorzystano dane źródłowe pozyskane z bazy Międzynarodowego Centrum Handlu ${ }^{8}$ na dwu-, cztero- oraz sześciocyfrowym poziomie dezagregacji w ramach Systemu Zharmonizowanego (Harmonised System, HS). Określenia zaawansowania technologicznego (high-tech, mid-tech, low-tech, surowco- i pracochłonne, artykuły rolne, surowce oraz niesklasyfikowane) analizowanych grup produktowych (czterocyfrowy poziom dezagregacji HS) dokonano na podstawie klasyfikacji przyjętej przez Konferencję Narodów Zjednoczonych ds. Handlu i Rozwoju (United Nations Conference on Trade and Development) ${ }^{9}$, korzystając ze stosownych tabel konwersji statystyki prowadzonej według Standardowej Klasyfikacji Handlu Międzynarodowego (Standard International Trade Classification, SITC; trzycyfrowy poziom dezagregacji).

Przewagę konkurencyjną zidentyfikowano dla grup produktów (czterocyfrowy poziom dezagregacji HS) na podstawie wartości wskaźnika RTA (relative trade advantage), będącego ilorazem wskaźników ujawnionej przewagi komparatywnej (revealed comparative advantage, RCA $)^{10}$ oraz penetracji importowej (import penetration, IMP) ${ }^{11}$. Intensywność wymiany wewnątrzgałęziowej (intra-industry trade, IIT) zmierzono indeksem Grubela-Lloyda ${ }^{12}$ obliczonym dla danych handlowych na sześciocyfrowym poziomie dezagregacji HS.

Zidentyfikowano również jej podkategorie składowe: handel poziomy (horizontal IIT, HIIT), pionowy - wysoka jakość (vertical-high quality IIT, VIIT-HQ), pionowy - niska jakość (vertical-low quality IIT, VIIT-LQ). By to uczynić, zastosowano metodę zaproponowaną przez Greenawaya, Hine’a i Milnera ${ }^{13}$, bazującą na założeniu, że wartość jednostkowa w przybliżeniu odzwierciedla jakość danego dobra (wyższa/

7 Zob. J. Staniszkis, Podwójna peryferyjność Polski, http://www.nowakonfederacja.pl/podwojna-peryferyjnosc-polski/ (dostęp 10.01.2015).

8 http://www.trademap.org (dostep 5.09.2016).

9 http://unctadstat.unctad.org/UnctadStatMetadata/Classifications/Methodology\&Classifications.html (dostęp 26.10.2012)

10 Zob. B. Balassa, Trade Liberalisation and “Revealed” Comparative Advantage, „The Manchester School” Vol. 33, Issue 2, May 1965.

11 IMP obliczany jest analogicznie jak RCA dla danych dotyczących importu. Przyjmuje się, że przewaga konkurencyjna istnieje, jeśli RTA $>1$.

12 Zob. H. Grubel, P. Lloyd, Intra-Industry Trade. The Theory and Measurement of International Trade in Differentiated Products, Macmillan, London 1975.

13 Zob. D. Greenaway, R. Hine, C. Milner, Country Specific Factors and the Pattern of Horizontal and Vertical Intra-Industry Trade in the UK, „WeltwirtschaftlichesArchiv” Vol. 130, No. 1, 1994 oraz D. Greenaway, R. Hine, C. Milner, Vertical and Horizontal Intra-Industry Trade: A Cross-Industry Analysis for the United Kingdom, „The Economic Journal” Vol. 105, No. 433, 1995. 
niższa cena to odpowiednio wyższa/niższa jakość dobra) ${ }^{14}$. Tym samym HIIT ma miejsce, jeśli stosunek średniej wartości dóbr będących przedmiotem eksportu i importu nie różni się o więcej niż +/-15\%. Z kolei VIIT-LQ/VIIT-HQ zachodzi wówczas, gdy ww. różnice jednostkowych wartości porównywanych dóbr eksportowanych i importowanych są odpowiednio mniejsze/większe niż $15 \%{ }^{15}$.

Warto także w tym miejscu zauważyć, że kraj o niższym przeciętnym dochodzie per capita powinien generalnie specjalizować się w eksporcie odmian o niższej jakości dobra zróżnicowanego (specjalizacja down-market), podczas gdy kraje bardziej rozwinięte, o wyższych przeciętnych dochodach per capita, powinny specjalizować się w eksporcie wysokiej jakości odmian dobra zróżnicowanego (specjalizacja up-market $)^{16}$.

Innym, istotnym wymiarem tego problemu jest także wpływ zagranicznych inwestycji bezpośrednich (ZIB) na charakterystykę strumieni handlowych. Uznaje się, że poziom skumulowanych inwestycji z kraju partnera handlowego oddziałuje pozytywnie zarówno na pionowy, jak i poziomy IIT w Polsce ${ }^{17}$. Intuicyjnie rzecz ujmując, na handel wewnątrzgałęziowy powinna wpływać także fragmentaryzacja procesów produkcji w skali międzynarodowej, choć z badań odnoszących się do Polski wynika, że taka prawidłowość nie zachodziła ${ }^{18}$.

\section{Polska specyfika zagrożenia pułapką średniego dochodu. Klątwa niemieckiej bliskości geograficznej?}

Za punkt wyjścia do rozważań nad perspektywami rozwoju relacji polsko-skandynawskich przyjęto autorską tezę o klątwie niemieckiej bliskości geograficznej.

14 Należy oczywiście pamiętać, że jest to jedynie umowne przybliżenie, choćby z uwagi na dostępność kompletnych danych handlowych na pożądanym poziomie dezagregacji oraz ich sporządzanie w USD, co wiąże się z problemem zmienności kursu walutowego.

15 Zob. także E. Czarny, K. Śledziewska, Międzynarodowa wspótpraca gospodarcza w warunkach kryzysu: wnioski dla Polski, PWE, Warszawa 2012, s. 184-186; E. Molendowski, Integracja handlowa w Nowych Państwach Członkowskich (UE-10). Doświadczenia i wnioski dla innych krajów Europy Środkowej i Wschodniej, Difin, Warszawa 2012, s. 39-54 oraz T. Brodzicki, K. Śledziewska, Determinanty wertykalnego i horyzontalnego handlu wewnątrzgatęziowego Polski. Analiza ekonometryczna, [w:] Handel międzynarodowy w rozwoju społeczno-ekonomicznym państw, red. S. Wydymus, M. Maciejewski, CeDeWu, Warszawa 2016, s. 46.

16 T. Brodzicki, K. Śledziewska, op.cit., s. 44.

17 Ibidem, s. 45. Zob. szerzej także Ł. Ambroziak, Wpływ bezpośrednich inwestycji zagranicznych na handel wewnątrzgałęziowy państw Grupy Wyszehradzkiej, Instytut Badań Rynku, Konsumpcji i Koniunktur, Warszawa 2013.

18 Zob. A. Cieślik, Wplyw przedsiębiorstw międzynarodowych na fragmentaryzację produkcji $i$ handel wewnątrzgałęziowy Polski z krajami OECD, „Gospodarka Narodowa” nr 10(206), 2008. 
Można ją interpretować w kategoriach specyficznie polskiej (a szerzej być może nawet środkowoeuropejskiej, charakterystycznej dla całej Grupy Wyszehradzkiej) odmiany pułapki średniego dochodu (middle-income trap). Problem ten, zidentyfikowany pierwotnie jako strukturalne wyzwanie dla krajów azjatyckich i latynoamerykańskich ${ }^{19}$, jest coraz częściej podejmowany w ramach badań naukowych ${ }^{20}$, przez komentatorów politycznych oraz stanowi zarazem jeden z kluczowych elementów wstępnej diagnozy Ministerstwa Rozwoju identyfikującej zagrożenia dla rozwoju polskiej gospodarki w średniookresowej perspektywie ${ }^{21}$.

Na podstawie przeglądu literatury przedmiotu można stwierdzić, że sednem pułapki średniego dochodu pozostaje kilka współwystępujących cech, spośród których zdecydowana większość odnosi się do dotychczasowej specyfiki rozwoju polskiej gospodarki. Są nimi:

- przedwczesne inwestowanie w przedsięwzięcia wiedzochłonne, niezapewniające odpowiedniej stopy zwrotu, a generujące marnotrawstwo środków publicznych ${ }^{22}$,

- silne otwarcie na napływ zagranicznego know-how, podnoszącego produktywność pracy, a przez to relatywną atrakcyjność zatrudnienia ${ }^{23}$,

- bardzo ograniczony rozwój własnych pomysłów, de facto uniemożliwiający przebicie bariery „szklanego sufitu”,

- utrzymywanie nacisku na relatywnie niskie koszty pracy jako podstawę wzrostu gospodarczego i poprawy konkurencyjności ${ }^{25}$.

19 Zob. I. Gill, H. Kharas, An East Asian Renaissance: Ideas for Economic Growth, The World Bank, Washington, D.C. 2007.

20 Zob. J.M. Radło, D. Ciesielska, Polska w pułapce średniego dochodu? Perspektywy konkurencyjności polskiej gospodarki i regionów, Difin, Warszawa 2013; Polska jako peryferie, red. T. Zarycki, Scholar, Warszawa 2016.

${ }_{21}$ Ministerstwo Rozwoju, Plan na rzecz Odpowiedzialnego Rozwoju, https://www.mr.gov.pl/media/14840/ Plan_na_rzecz_Odpowiedzialnego_Rozwoju_prezentacja.pdf (dostęp 28.02.2016).

22 I. Gill, H. Kharas, The Middle-Income Trap Turns Ten, „Policy Research Working Paper” No. 7403, The World Bank, Washington, D.C., August 2015, s. 7. W polskich realiach wiąże się to z dylematem realizacji priorytetów określanych przez Komisję Europejską dla kolejnych perspektyw finansowych, a interpretowanych przez pryzmat potrzeb polskiej gospodarki na jej obecnym poziomie rozwoju. Zdolność do kreowania zaawansowanych innowacji nie zostanie osiągnięta bez trwałych podstaw w postaci twardych inwestycji infrastrukturalnych.

23 B. Eichengreen, D. Park, K. Shin, When Fast Growing Economies Slow Down: International Evidence and Implications for China, „NBER Working Paper” No. 16919, March 2011. Polska jako kraj słabiej rozwinięty gospodarczo poszukuje strukturalnego przyspieszenia poprzez otwarcie na napływ inwestycji zagranicznych, jednak wciąż bez spójnej wizji co do ich pożądanego udziału oraz przełożenia na lokalne i regionalne systemy gospodarcze.

24 K. Ohno, Avoiding the Middle-Income Trap Renovating Industrial Policy Formulation in Vietnam, „ASEAN Economic Bulletin” Vol. 26, No. 1, April 2009. Kapitał zagraniczny, oferując generalnie bardziej atrakcyjne warunki pracy i płacy, uczestniczy w drenażu mózgów (zarówno w wymiarze wewnętrznym, jak i zewnętrznym), osłabiając tym samym potencjał do kreowania innowacji.

25 E. Paus, Confronting the Middle Income Trap: Insights from Small Latecomers, „Studies in Comparative International Development" Vol. 47, Issue 2, June 2012, s. 116. 
Warto zwłaszcza zwrócić uwagę na kwestię pozornej europeizacji Polski, która zaczyna wręcz przypominać latynoamerykanizację ${ }^{26}$. Innymi słowy, dylemat polega na tym, czy w warunkach napływu zagranicznych inwestycji i postępującej fragmentaryzacji korporacyjnych łańcuchów produkcyjnych działające w Polsce przedsiębiorstwa (oddziały zagranicznych firm, dostawcy, dalsi kooperanci) nie zaczynają utrwalać modelu maquiladoras. Ich głównymi atutami w konkurencji z innymi lokalizacjami są relatywnie niskie koszty pracy, rosnąca wydajność, zdolność do szybkiego wdrażania zagranicznych technologii przy jednoczesnej słabości własnego systemu wspierania innowacyjności oraz bliskość geograficzna (a przez to atrakcyjność) głównego partnera handlowego. Dodatkowo funkcjonowanie w ramach specjalnych stref ekonomicznych przekłada się na tzw. efekt enklawy - niewykształcenia spodziewanych powiązań kooperacyjnych z lokalnymi przedsiębiorcami. Następuje tu więc klasyczny błąd złożenia racjonalności na poziomie mikro (Niemcy jako atrakcyjny rynek dla firm, źródło technologii oraz partner, od którego można pozyskać cenne doświadczenia ${ }^{27}$ ) z racjonalnością na poziomie makro (dotychczasowy model rozwoju wymaga zasadniczej korekty).

Analiza specyfiki polsko-niemieckich relacji handlowych dość jednoznacznie wskazuje na fakt, że polski eksport oparty jest w dużej mierze na strumieniach zaopatrzeniowych, istotnych dla korporacyjnej fragmentaryzacji produkcji, zwłaszcza w sektorze motoryzacyjnym (HS 87) oraz maszynowym (HS 84) ${ }^{28}$. Branże te wymagają takiego rozmieszczenia firm poddostawców w ramach korporacyjnych łańcuchów tworzenia wartości dodanej, by w maksymalnym stopniu eksploatować przewagi kosztowe i efektywnościowe, a tym samym realnie blokują możliwość rozwoju krajowych innowacyjnych projektów. Efektywna absorpcja zagranicznych (niemieckich) technologii stanowi o istocie współczesnych wyzwań rozwojowych Polski - specjalizacji w produkcji dóbr o średnim poziomie zaawansowania technologicznego w warunkach rosnącej presji konkurencyjnej ze strony tańszych producentów z Azji. Konieczne jest zatem określenie scenariusza odejścia od konkurencji opartej

26 J. Staniszkis, Polska bieda, „Do Rzeczy” nr 19/170, 9-15 maja 2016, s. 97.

27 Zob. szerzej koncepcja uczenia się przez eksport (learning by exporting) w: E. Mińska-Struzik, Od eksportu do innowacji. Uczenie się przez eksport polskich przedsiębiorstw, Difin, Warszawa 2014.

28 Zob. szerzej B. Michalski, Umiędzynarodowienie sektora mid-tech na przykładzie wymiany handlowej sektora samochodowego w Polsce w latach 2004-2012, „Ekonomia Międzynarodowa” nr 6, 2014; B. Michalski, Konsekwencje członkostwa w Unii Europejskiej dla polsko-niemieckiej wymiany handlowej dobrami mid-tech i high-tech, [w:] Jabłko niezgody. Regionalne wyzwania wspótczesnej gospodarki światowej, red. nauk. B. Drelich-Skulska, M. Domiter, W. Michalczyk, „Prace Naukowe Uniwersytetu Ekonomicznego we Wrocławiu" nr 407, Wydawnictwo Uniwersytetu Ekonomicznego, Wrocław 2015; B. Michalski, Polsko-niemiecka wymiana handlowa $w$ sektorze maszynowym w latach 2001-2013. Ocena szans i zagrożeń, „Zeszyty Naukowe Uniwersytetu Szczecińskiego” nr 857, „Studia i Prace Wydziału Nauk Ekonomicznych i Zarządzania” nr 41, Wydawnictwo Naukowe Uniwersytetu Szczecińskiego, Szczecin 2015. 
na kosztach i przewagach stricte lokalizacyjnych na rzecz stopniowego uniezależniania się poprzez selektywną politykę przyciągania pożądanego (w ujęciu sektorowym oraz technologicznym) kapitału zza granicy, konsekwentnego wspierania krajowych innowacji oraz wyrównywania warunków konkurencji dla rodzimych firm.

\section{Charakterystyka relacji handlowych z krajami skandynawskimi w latach 2001-2015. Identyfikacja przewag konkurencyjnych}

Rozwój relacji handlowych z krajami skandynawskimi przebiegał w analizowanym okresie w zróżnicowany sposób. Głównym rynkiem eksportowym (zob. rys. 1) stała się Szwecja (15,2\% średnioroczny wzrost obrotów), natomiast Dania i Norwegia zamieniały się pozycjami jako drugi/trzeci odbiorca (średnioroczny wzrost odpowiednio 10,3 oraz 18,8\%). Eksport do Finlandii także stopniowo rósł, ale jego dynamika (średni wzrost 15\%) nie przełożyła się na zmianę pozycji. Postępująca dywersyfikacja geograficzna polskiego eksportu wpłynęła również na sam kierunek skandynawski, bowiem jego łączny udział po nieznacznym wzroście w latach 2001-2003 (poziom 8,5-8,8\%) zaczął systematycznie maleć (w roku 2015 ok. 6,5\%).

Rysunek 1. Polski eksport do krajów skandynawskich w latach 2001-2015 (w mld USD)

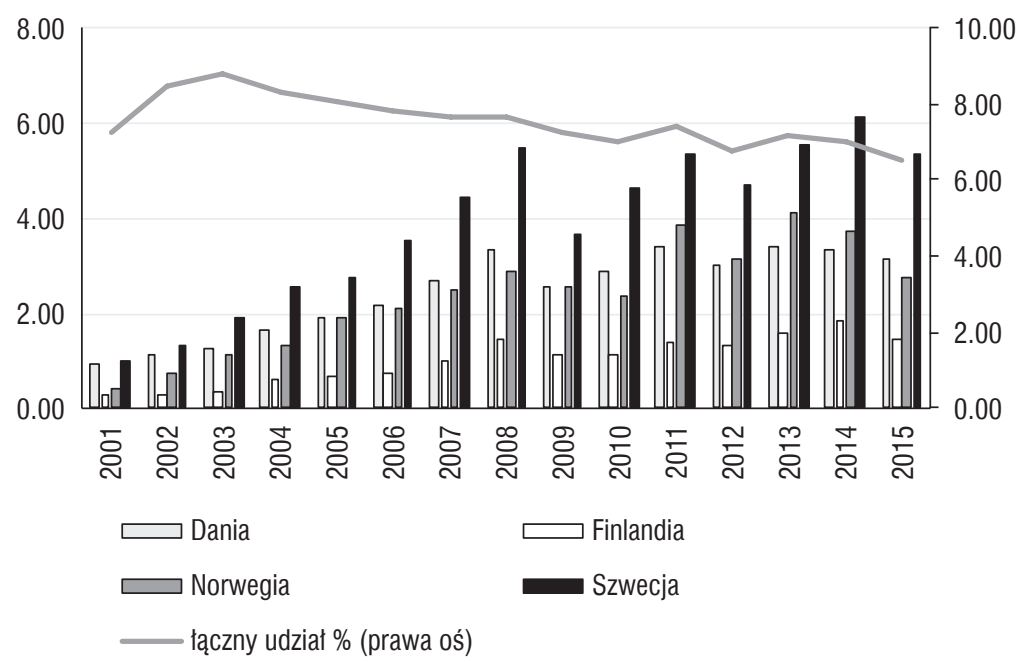

Źródło: Opracowanie własne na podstawie http://www.trademap.org (dostęp 5.09.2016). 
O sile polskiego eksportu na poszczególne rynki decydowały następujące sektory:

- w przypadku Danii - tworzywa sztuczne (HS 39), maszyny (HS 84), artykuły elektryczne i elektroniczne (HS 85) oraz meble (HS 94),

- w przypadku Finlandii - żeliwo i stal (HS 72), maszyny (HS 84) oraz artykuły elektryczne i elektroniczne (HS 85),

- w przypadku Norwegii - artykuły z żeliwa i stali (HS 73), branża motoryzacyjna (HS 87) oraz stoczniowa (HS 89),

- w przypadku Szwecji - maszyny (HS 84), artykuły elektryczne i elektroniczne (HS 85) oraz branża motoryzacyjna (HS 87).

Analizując dynamikę zmian w imporcie, ponownie głównym partnerem pozostawała Szwecja, a drugim najważniejszym dostawcą skandynawskim stała się Norwegia, mimo że w początkowych latach wyraźnie wyprzedzały ją firmy duńskie i fińskie. Systematycznie malał łączny udział rynków skandynawskich jako źródła zaopatrzenia (spadek z 7,3\% do 5,1\%).

Rysunek 2. Polski import z krajów skandynawskich w latach 2001-2015 (w mld USD)

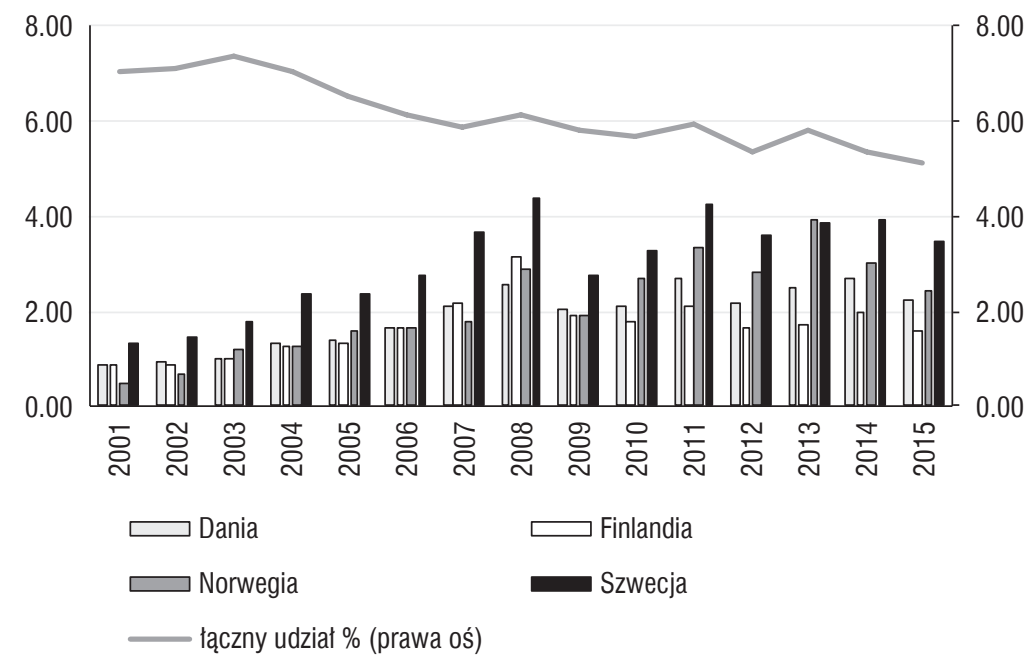

Źródło: Jak do rysunku 1.

W strukturze importu z objętych analizą krajów dominowały przede wszystkim:

- w przypadku Danii - zwierzęta żywe (HS 01), mięso (HS 02), maszyny (HS 84) oraz artykuły elektryczne i elektroniczne (HS 85),

- w przypadku Finlandii - tworzywa sztuczne (HS 39), branża papiernicza (HS 48), żelazo i stal (HS 72) oraz maszyny (HS 84), 
- w przypadku Norwegii - ryby (HS 03), wyroby z aluminium (HS 76), branża stoczniowa (HS 89),

- w przypadku Szwecji - maszyny (HS 84), artykuły elektryczne i elektroniczne (HS 85) oraz branża motoryzacyjna (HS 87).

Porównanie dominujących branż w dwustronnych relacjach handlowych (eksportimport) pozwala domniemywać, że wskaźniki intensywności wymiany wewnątrzgałęziowej będą stosunkowo wyższe zwłaszcza w przypadku handlu polsko-szwedzkiego. Przypuszczenie to zostanie zweryfikowane w dalszej części rozważań.

Rysunek 3. Ewolucja struktury technologicznego zaawansowania eksportu Polski do Danii w latach 2001-2015 (w \%)

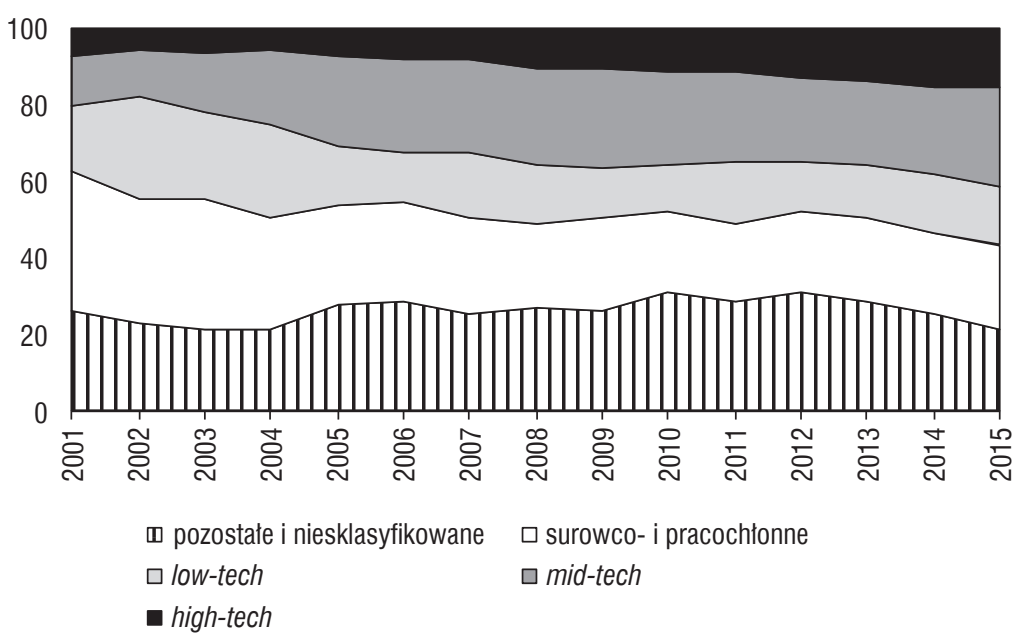

Źródło: Opracowanie własne na podstawie http://www.trademap.org (dostęp 5.09.2016) oraz http://unctadstat.unctad.org/UnctadStatMetadata/Classifications/Methodology\&Classifications.html (dostęp 26.10.2012).

Kolejnym etapem badania była identyfikacja ewolucji struktury technologicznego zaawansowania polskiego eksportu oraz importu, a także salda bilansu handlowego z każdym z krajów. Wyniki tej części analizy zostały przedstawione na rysunkach 4-10 oraz w tabelach 1-4. Ponieważ o wysokiej ocenie konkurencyjności gospodarek świadczy współcześnie m.in. zdolność do produkowania dóbr technologicznie zaawansowanych (high-tech), warto zwrócić uwagę na zmiany w obrębie tej kategorii po stronie polskiego eksportu.

W przypadku Danii udział ten, jakkolwiek wciąż zbyt niski, powoli rósł, głównie za sprawą leków (HS 3004), odwracając jednocześnie dotychczasowy strumień importowy. W relacjach z Finlandią udział polskiego eksportu high-tech podlegał wahaniom, ale w tej grupie dóbr ekspansję odnotowały leki (HS 3004) oraz maszyny 
do automatycznego przetwarzania danych (HS 8471). Jeśli chodzi o import, zanotowano korzystną tendencję do zmniejszania udziału high-tech, a stało się to głównie za przyczyną spadającej sprzedaży telefonów (HS 8517) ${ }^{29}$ oraz aparatury nadawczej dla radiofonii i telewizji (HS 8525). W stosunkach z Norwegią handel zaawansowany technologicznie był na bardzo niskim poziomie. Główną grupą produktową po stronie eksportu były leki (HS 3004), a norweski import high-tech do Polski stracił swój udział głównie za sprawą sztucznego grafitu (HS 3801). Najistotniejszy partner handlowy Polski wśród krajów skandynawskich - Szwecja - notował wahania udziału dóbr high-tech. W polskim eksporcie dominowały przede wszystkim telefony (HS 8517) oraz telewizory (HS 8528), natomiast w imporcie ze Szwecji główną kategorię high-tech stanowiły leki (HS 3004) oraz elektroniczne układy scalone (HS 8542).

Rysunek 4. Ewolucja struktury technologicznego zaawansowania importu Polski z Danii w latach 2001-2015 (w \%)

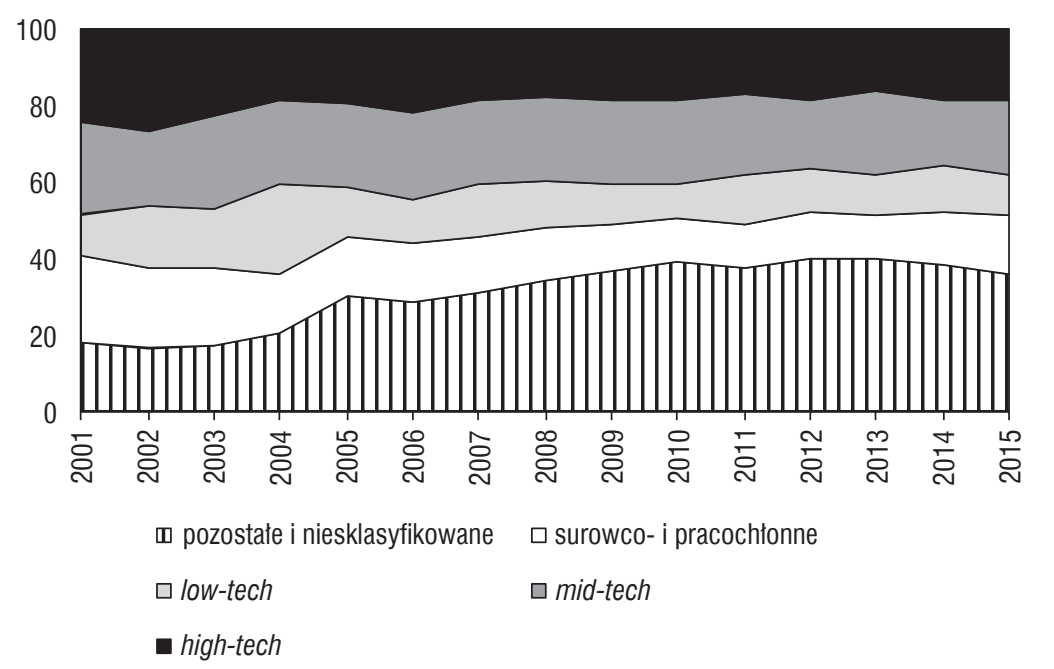

Źródło: Jak do rysunku 3.

Konsekwencją zróżnicowanej struktury technologicznego zaawansowania polskiego eksportu i importu do/z krajów skandynawskich były także odmienne wyniki po stronie bilansu handlowego. Widać to przede wszystkim w relacjach z Finlandią, co skutkuje trwale ujemnym wynikiem, nawet w kategoriach uznawanych za naturalny atut polskiej gospodarki (dobra surowco- i pracochłonne, low-tech). Z pozostałymi krajami saldo bilansu handlowego pozostawało zwykle dodatnie i to niemal we

29 Efekt delokalizacji produkcji. 
wszystkich podkategoriach (wyjątek stanowi import dóbr high-tech z Danii w latach 2001-2012).

Rysunek 5. Ewolucja struktury technologicznego zaawansowania eksportu Polski do Finlandii w latach 2001-2015 (w \%)

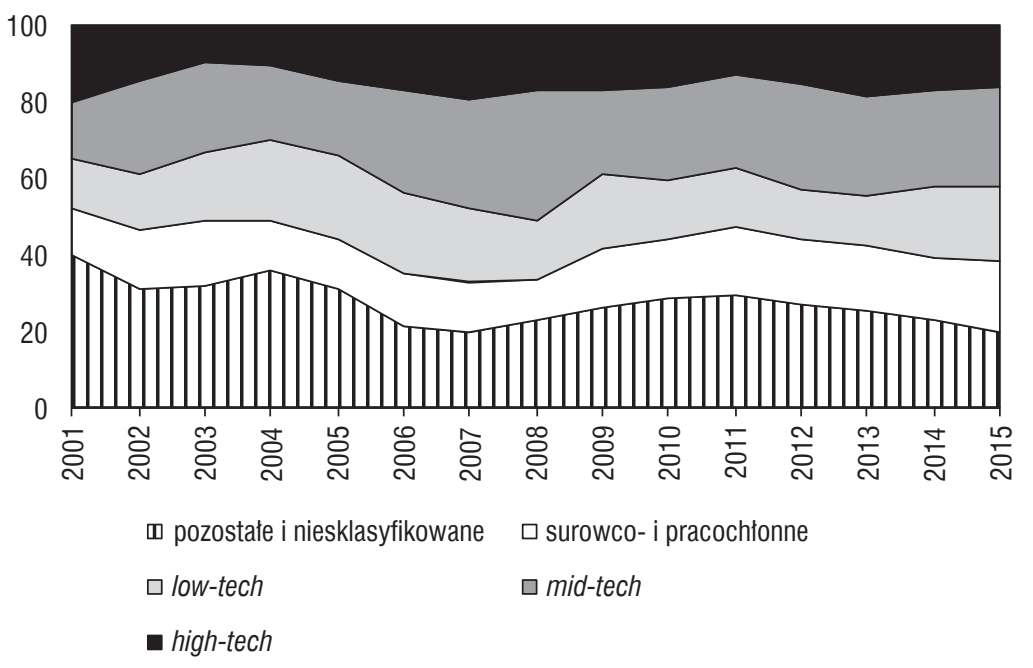

Źródło: Jak do rysunku 3.

Rysunek 6. Ewolucja struktury technologicznego zaawansowania importu Polski z Finlandii w latach 2001-2015 (w \%)

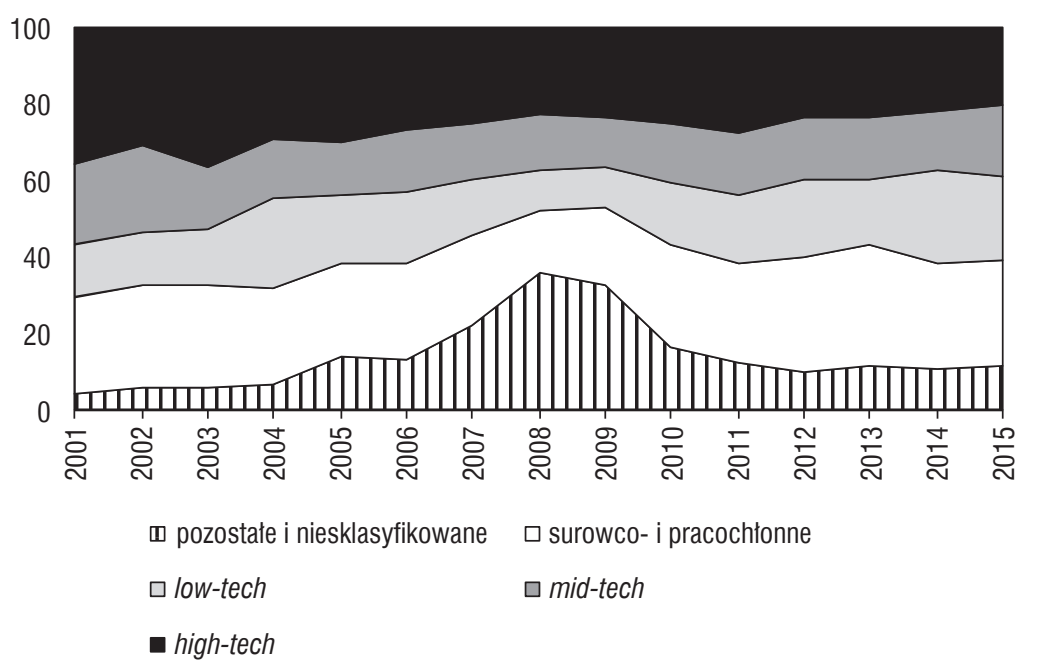

Źródło: Jak do rysunku 3. 
Rysunek 7. Ewolucja struktury technologicznego zaawansowania eksportu Polski do Norwegii w latach 2001-2015 (w \%)

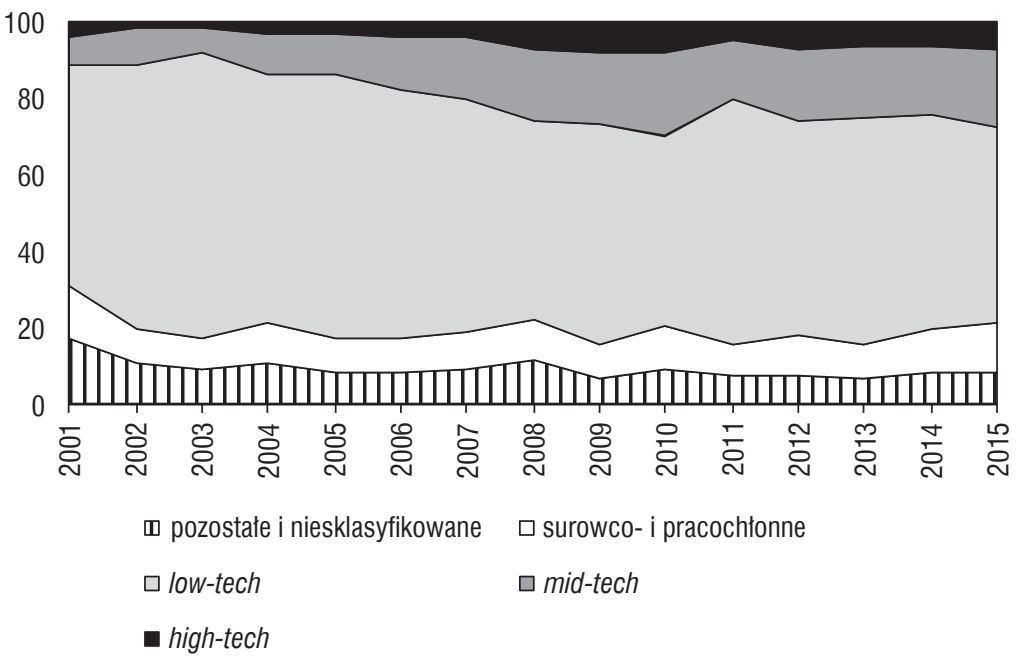

Źródło: Jak do rysunku 3.

Rysunek 8. Ewolucja struktury technologicznego zaawansowania importu Polski z Norwegii w latach 2001-2015 (w \%)

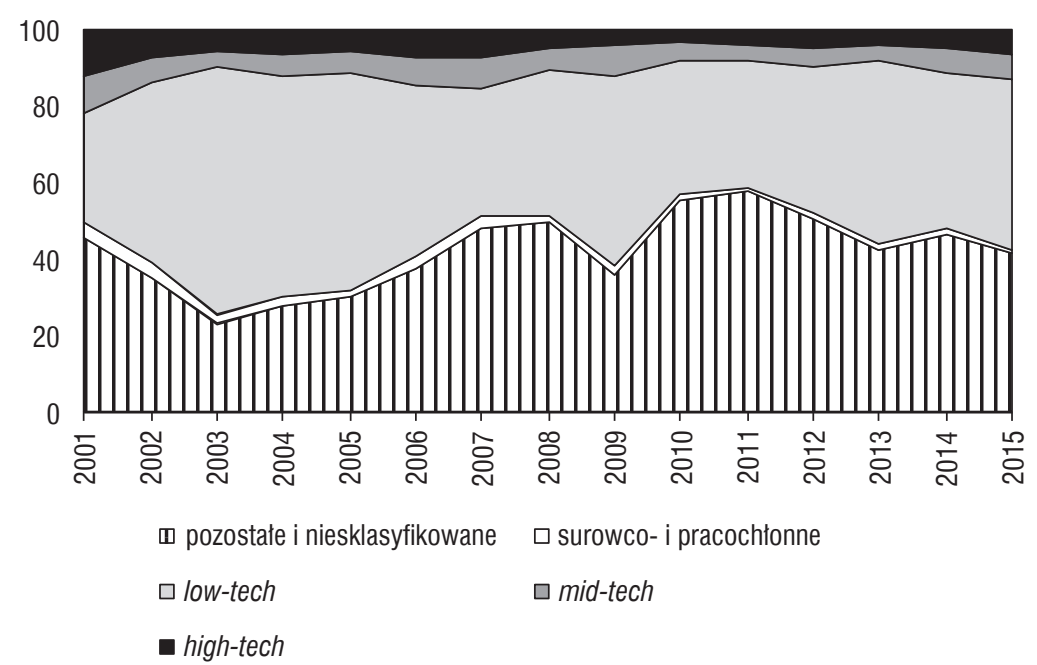

Źródło: Jak do rysunku 3. 
Rysunek 9. Ewolucja struktury technologicznego zaawansowania eksportu Polski do Szwecji w latach 2001-2015 (w \%)

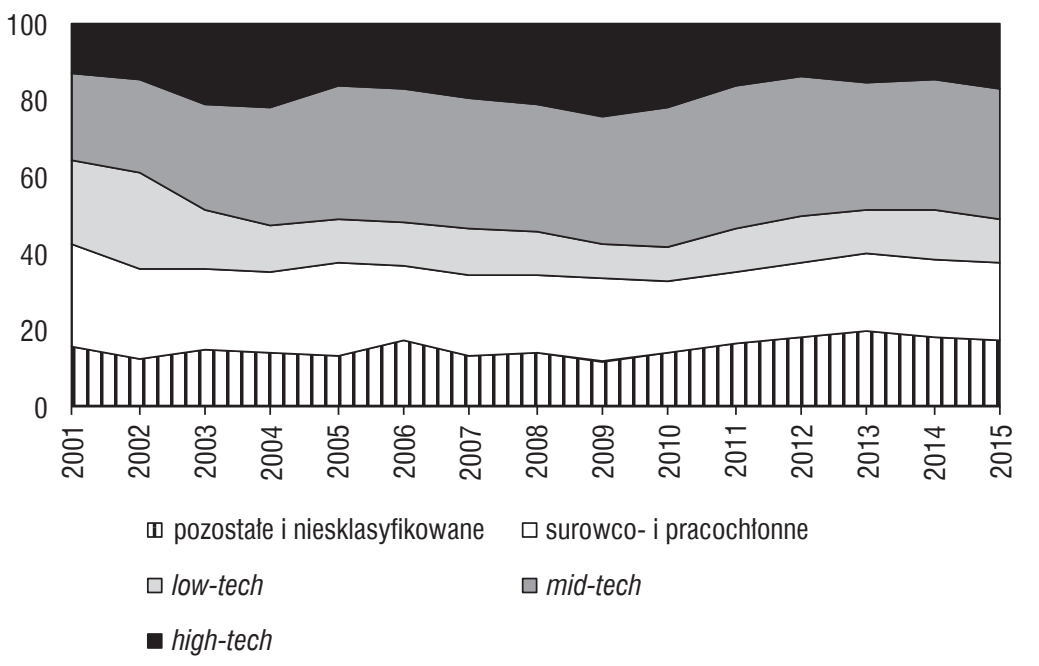

Źródło: Jak do rysunku 3.

Rysunek 10. Ewolucja struktury technologicznego zaawansowania importu Polski ze Szwecji w latach 2001-2015 (w \%)

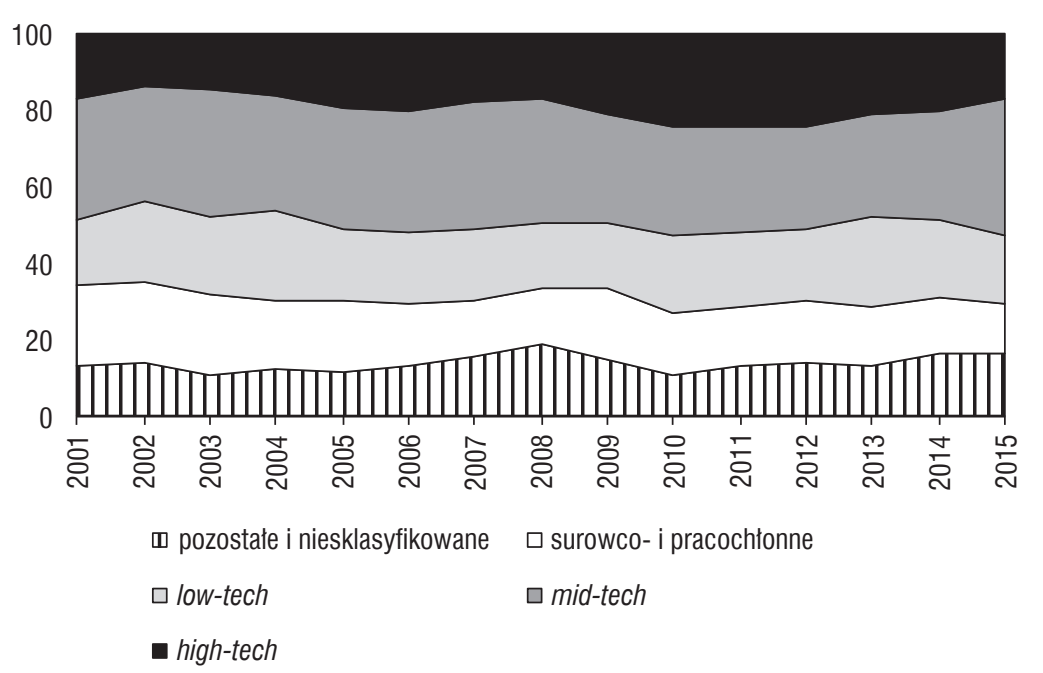

Źródło: Jak do rysunku 3. 
Tabela1. Dekompozycja salda bilansu handlowego Polski z Danią w latach 2001-2015 (w mld USD)

\begin{tabular}{|l|r|r|r|r|r|r|r|r|r|r|r|r|r|r|r|}
\cline { 2 - 16 } \multicolumn{1}{c|}{} & 2001 & 2002 & 2003 & 2004 & 2005 & 2006 & 2007 & 2008 & 2009 & 2010 & 2011 & 2012 & 2013 & 2014 & 2015 \\
\hline Poz. & 0,08 & 0,10 & 0,10 & 0,09 & 0,11 & 0,14 & 0,02 & 0,01 & $-0,10$ & 0,09 & $-0,04$ & 0,07 & $-0,01$ & $-0,16$ & $-0,14$ \\
\hline SP & 0,14 & 0,17 & 0,23 & 0,28 & 0,25 & 0,30 & 0,36 & 0,36 & 0,35 & 0,34 & 0,38 & 0,38 & 0,45 & 0,35 & 0,35 \\
\hline LT & 0,06 & 0,15 & 0,12 & 0,08 & 0,11 & 0,11 & 0,16 & 0,21 & 0,11 & 0,16 & 0,18 & 0,13 & 0,19 & 0,19 & 0,22 \\
\hline MT & $-0,08$ & $-0,05$ & $-0,04$ & 0,02 & 0,14 & 0,15 & 0,18 & 0,24 & 0,19 & 0,24 & 0,25 & 0,28 & 0,22 & 0,30 & 0,36 \\
\hline HT & $-0,14$ & $-0,18$ & $-0,14$ & $-0,15$ & $-0,13$ & $-0,19$ & $-0,18$ & $-0,09$ & $-0,10$ & $-0,05$ & $-0,08$ & $-0,01$ & 0,05 & 0,02 & 0,07 \\
\hline Razem & 0,06 & 0,19 & 0,27 & 0,32 & 0,49 & 0,51 & 0,53 & 0,73 & 0,45 & 0,78 & 0,70 & 0,87 & 0,90 & 0,70 & 0,86 \\
\hline
\end{tabular}

Objaśnienia: Poz. - pozostałe i niesklasyfikowane, SP - surowco- i pracochłonne, LT - low-tech, MT - mid-tech, HT - high-tech.

Źródło: Opracowanie własne na podstawie http://www.trademap.org (dostęp 5.09.2016) oraz http://unctadstat.unctad.org/UnctadStatMetadata/Classifications/Methodology\&Classifications.html (dostęp 26.10.2012).

Tabela 2. Dekompozycja salda bilansu handlowego Polski z Finlandią w latach 2001-2015 (w mld USD)

\begin{tabular}{|l|r|r|r|r|r|r|r|r|r|r|r|r|r|r|r|}
\cline { 2 - 14 } \multicolumn{1}{c|}{} & 2001 & 2002 & 2003 & 2004 & 2005 & 2006 & 2007 & 2008 & 2009 & 2010 & 2011 & 2012 & 2013 & 2014 & 2015 \\
\hline Poz. & 0,08 & 0,04 & 0,04 & 0,13 & 0,03 & $-0,05$ & $-0,28$ & $-0,77$ & $-0,33$ & 0,03 & 0,16 & 0,20 & 0,21 & 0,21 & 0,12 \\
\hline SP & $-0,18$ & $-0,19$ & $-0,21$ & $-0,24$ & $-0,22$ & $-0,31$ & $-0,37$ & $-0,37$ & $-0,22$ & $-0,29$ & $-0,30$ & $-0,26$ & $-0,26$ & $-0,26$ & $-0,16$ \\
\hline LT & $-0,08$ & $-0,07$ & $-0,09$ & $-0,16$ & $-0,08$ & $-0,15$ & $-0,12$ & $-0,10$ & 0,01 & $-0,12$ & $-0,16$ & $-0,15$ & $-0,09$ & $-0,15$ & $-0,07$ \\
\hline MT & $-0,13$ & $-0,13$ & $-0,08$ & $-0,08$ & $-0,04$ & $-0,06$ & $-0,04$ & 0,04 & 0,00 & 0,00 & 0,01 & 0,10 & 0,14 & 0,17 & 0,09 \\
\hline HT & $-0,24$ & $-0,22$ & $-0,34$ & $-0,30$ & $-0,29$ & $-0,31$ & $-0,35$ & $-0,45$ & $-0,27$ & $-0,26$ & $-0,40$ & $-0,18$ & $-0,10$ & $-0,13$ & $-0,08$ \\
\hline Razem & $-0,55$ & $-0,57$ & $-0,67$ & $-0,65$ & $-0,61$ & $-0,87$ & $-1,15$ & $-1,64$ & $-0,81$ & $-0,64$ & $-0,70$ & $-0,30$ & $-0,11$ & $-0,16$ & $-0,11$ \\
\hline
\end{tabular}

Objaśnienia jak do tabeli 1.

Źródło: Jak do tabeli 1.

Tabela 3. Dekompozycja salda bilansu handlowego Polski z Norwegią w latach 2001-2015 ( $w$ mld USD)

\begin{tabular}{|l|r|r|r|r|r|r|r|r|r|r|r|r|r|r|r|}
\cline { 2 - 16 } \multicolumn{1}{l|}{} & 2001 & 2002 & 2003 & 2004 & 2005 & 2006 & 2007 & 2008 & 2009 & 2010 & 2011 & 2012 & 2013 & 2014 & 2015 \\
\hline Poz. & $-0,15$ & $-0,16$ & $-0,18$ & $-0,21$ & $-0,33$ & $-0,45$ & $-0,63$ & $-1,08$ & $-0,50$ & $-1,26$ & $-1,63$ & $-1,18$ & $-1,39$ & $-1,10$ & $-0,77$ \\
\hline SP & 0,04 & 0,05 & 0,07 & 0,10 & 0,14 & 0,15 & 0,21 & 0,24 & 0,17 & 0,20 & 0,25 & 0,28 & 0,32 & 0,37 & 0,32 \\
\hline LT & 0,09 & 0,18 & 0,06 & 0,13 & 0,40 & 0,62 & 0,93 & 0,40 & 0,54 & 0,24 & 1,36 & 0,67 & 0,55 & 0,88 & 0,32 \\
\hline MT & $-0,02$ & 0,03 & 0,02 & 0,07 & 0,11 & 0,18 & 0,25 & 0,37 & 0,33 & 0,38 & 0,47 & 0,45 & 0,58 & 0,48 & 0,42 \\
\hline HT & $-0,04$ & $-0,04$ & $-0,04$ & $-0,04$ & $-0,03$ & $-0,04$ & $-0,03$ & 0,08 & 0,12 & 0,10 & 0,03 & 0,10 & 0,12 & 0,09 & 0,03 \\
\hline Razem & $-0,08$ & 0,06 & $-0,07$ & 0,05 & 0,29 & 0,46 & 0,72 & 0,01 & 0,67 & $-0,33$ & 0,48 & 0,31 & 0,18 & 0,71 & 0,32 \\
\hline
\end{tabular}

Objaśnienia jak do tabeli 1.

Źródło: Jak do tabeli 1. 
Tabela 4. Dekompozycja salda bilansu handlowego Polski ze Szwecją w latach 2001-2015 (w mld USD)

\begin{tabular}{|l|r|r|r|r|r|r|r|r|r|r|r|r|r|r|r|}
\cline { 2 - 15 } \multicolumn{1}{l|}{} & 2001 & 2002 & 2003 & 2004 & 2005 & 2006 & 2007 & 2008 & 2009 & 2010 & 2011 & 2012 & 2013 & 2014 & 2015 \\
\hline Poz. & $-0,03$ & $-0,04$ & 0,09 & 0,06 & 0,09 & 0,23 & 0,00 & $-0,08$ & 0,02 & 0,30 & 0,30 & 0,34 & 0,60 & 0,47 & 0,33 \\
\hline SP & $-0,02$ & 0,01 & 0,04 & 0,12 & 0,22 & 0,25 & 0,42 & 0,49 & 0,26 & 0,35 & 0,39 & 0,38 & 0,51 & 0,65 & 0,67 \\
\hline LT & $-0,01$ & 0,03 & $-0,06$ & $-0,25$ & $-0,10$ & $-0,15$ & $-0,12$ & $-0,10$ & $-0,12$ & $-0,24$ & $-0,22$ & $-0,12$ & $-0,29$ & $-0,01$ & $-0,06$ \\
\hline MT & $-0,21$ & $-0,11$ & $-0,04$ & 0,07 & 0,21 & 0,36 & 0,31 & 0,37 & 0,43 & 0,76 & 0,81 & 0,75 & 0,82 & 0,99 & 0,61 \\
\hline HT & $-0,09$ & 0,00 & 0,14 & 0,19 & 0,01 & 0,05 & 0,22 & 0,41 & 0,29 & 0,23 & $-0,13$ & $-0,21$ & 0,03 & 0,09 & 0,31 \\
\hline Razem & $-0,36$ & $-0,12$ & 0,16 & 0,20 & 0,44 & 0,74 & 0,83 & 1,09 & 0,88 & 1,40 & 1,15 & 1,14 & 1,67 & 2,19 & 1,86 \\
\hline
\end{tabular}

Objaśnienia jak do tabeli 1.

Źródło: Jak do tabeli 1.

Ostatnim etapem analizy przy użyciu danych na czterostopniowym poziomie dezagregacji była identyfikacja tych grup towarowych, które charakteryzowały się w roku 2015 relatywną przewagą konkurencyjną. Dodatkowo wprowadzono dwa warunki brzegowe:

- wzięto pod uwagę tylko te grupy, w ramach których odnotowano zarówno strumień eksportowy, jak i importowy,

- wzięto pod uwagę tylko te grupy, których udział w eksporcie Polski do analizowanego kraju przekraczał 1\% w roku 2015.

W oparciu o tak określone kryteria polscy eksporterzy dysponowali przewagą konkurencyjną w następujących grupach (wyliczenie ograniczone do pięciu o najwyższej wartości wskaźnika RTA):

- w przypadku Danii - HS 1601 (kiełbasy), HS 8516 (podgrzewacze, grzałki, lokówki, żelazka, urządzenia elektrotermiczne), HS 8537 (tablice, panele itp. do elektrycznego sterowania lub rozdziału energii elektrycznej), HS 8701 (ciągniki drogowe) oraz HS 8703 (samochody osobowe),

- w przypadku Finlandii - HS 3004 (leki pakowane w odmierzone dawki do sprzedaży detalicznej), HS 3923 (artykuły z tworzyw sztucznych do transportu lub pakowania towarów), HS 7204 (odpady i złom żeliwa i stali), HS 8471 (maszyny do automatycznego przetwarzania danych) oraz HS 9401 (meble do siedzenia),

- w przypadku Norwegii - HS 3004 (jw.), HS 8702 (autobusy), HS 8906 (jednostki pływające), HS 9401 (jw.) oraz HS 9403 (pozostałe meble i ich części),

- w przypadku Szwecji - HS 1602 (inne mięso, podroby przetworzone lub zakonserwowane), HS 7308 (konstrukcje, części konstrukcje, płyty, pręty, kątowniki itp. z żelaza i stali), HS 8471 (jw.), HS 8528 (monitory, rzutniki, telewizory) oraz HS 9404 (stelaże pod materace, artykuły pościelowe i podobne wyposażenie). 


\section{Intensywność handlu wewnątrzgałęziowego Polski z Danią, Finlandią Norwegią i Szwecją}

Wskaźnik intensywności wymiany wewnątrzgałęziowej (wartość indeksu GL) obliczono w pierwszym kroku dla danych handlowych ogółem (tab. 5-8). Na drugim etapie, $z$ uwagi na fakt, że najważniejsze strumienie eksportowe i importowe w polskim handlu ze Skandynawią obejmowały zasadniczo różne sektory (komplementarność struktur), do szczegółowej analizy intensywności handlu wewnątrzgałęziowego wybrano jedynie te, w ramach których współpraca przebiegała w obydwu kierunkach (potencjalna substytucyjność). I tak dla Danii były to HS 39, HS 84 i HS 85, dla Finlandii - HS 72, HS 84 i HS 85, dla Norwegii - HS 84 i HS 89, natomiast dla Szwecji HS 84, HS 85 i HS 87.

Uzyskane wyniki wskazują, że wartość indeksu GL dla poszczególnych krajów skandynawskich nie przekraczała $30 \%$. Udziały podkategorii handlu wewnątrzgałęziowego (HIIT, VIIT-LQ oraz VIIT-HQ) odzwierciedlały wspomnianą wyżej prawidłowość, zgodnie z którą kraj słabiej rozwinięty (Polska) specjalizuje się w eksporcie odmian o niższej jakości dobra zróżnicowanego (przewaga subkategorii VIIT-LQ). Nie potwierdziło się jednocześnie wcześniejsze przypuszczenie, że wartość indeksu GL dla handlu Polski ze Szwecją będzie wyższa z uwagi na występowanie tych samych branż w strukturze eksportu i importu.

Ciekawych obserwacji dostarcza z kolei ewolucja wartości indeksu GL dla wybranych sektorów. Warto zwrócić przede wszystkim uwagę na trzy przypadki: handel polsko-duński w sektorze tworzyw sztucznych (HS 39), polsko-norweski w przemyśle stoczniowym (HS 89; indeks GL przekraczający poziom 70\%) oraz do pewnego stopnia polsko-szwedzki w sektorze samochodowym (HS 87).

Ten pierwszy obejmuje przede wszystkim produkty z polimerów etylenu (HS 3920 oraz HS 3923; odpowiednio grupy high-tech i mid-tech) oraz innych tworzyw sztucznych (HS 3926; grupa produktowa mid-tech). Polska specjalizuje się jednak w tańszych, czyli niższych jakościowo odmianach tych produktów (przewaga komponentu VIIT-LQ).

Intensywna współpraca $\mathrm{z}$ Norwegią w przemyśle stoczniowym (sektor i jego grupy produktowe klasyfikowane w całości jako low-tech) obejmuje zwłaszcza tankowce (HS 890120) oraz inne jednostki do przewozu towarów i osób (HS 890190). Pozytywnym zjawiskiem jest wyraźne utrwalanie się polskich przewag w produkcji dóbr wyższych jakościowo (zob. udziały HIIT oraz VIIT-HQ).

Ostatni przypadek handlu wewnątrzgałęziowego ze Szwecją w sektorze samochodowym (sektor i jego grupy produktowe klasyfikowane w całości jako mid-tech) 
koncentruje się przede wszystkim w obszarze ciągników drogowych (HS 870120), autobusów z silnikami wysoko- i średnioprężnymi (HS 870210), pojazdów silnikowych do transportu towarów o masie powyźej 5 t (HS 870421) oraz części i akcesoriów nadwozia do wyżej wymienionych (HS 870829). Zlokalizowane w Polsce firmy realizują coraz bardziej zaawansowane fazy cyklu produkcyjnego (przewaga komponentu VIIT-HQ), co świadczy o ich stosunkowo dobrej pozycji w ramach sieci korporacyjnych. Można przypuszczać, że jest to długotrwały efekt inwestycji koncernu Volvo oraz Scania. Branża charakteryzuje się jednak wysokimi barierami wejścia (kosztami utopionymi związanymi z rozpoczęciem działalności), stąd w ocenie autora mało prawdopodobne jest, że ewentualne korzystne efekty uczenia się przez eksport przełożą się na uruchomienie stricte polskich projektów produkcyjnych.

Tabela 5. Intensywność i struktura polsko-duńskiego handlu wewnątrzgałęziowego w latach 2001-2015 (ogółem oraz wybrane działy HS)

\begin{tabular}{|l|r|r|r|r|r|r|r|r|r|r|r|r|r|r|r|}
\cline { 2 - 14 } \multicolumn{1}{c|}{} & 2001 & 2002 & 2003 & 2004 & 2005 & 2006 & 2007 & 2008 & 2009 & 2010 & 2011 & 2012 & 2013 & 2014 & 2015 \\
\hline $\begin{array}{l}\text { Indeks GL } \\
\text { ogółem }\end{array}$ & 19,8 & 17,1 & 25,1 & 32,3 & 24,1 & 27,0 & 28,9 & 26,5 & 26,2 & 25,8 & 29,2 & 24,1 & 25,2 & 28,4 & 25,5 \\
\hline HIIT & 1,8 & 1,6 & 4,7 & 8,4 & 3,1 & 5,4 & 5,0 & 4,8 & 3,2 & 6,3 & 4,7 & 5,0 & 5,0 & 6,0 & 4,5 \\
\hline VIIT-LQ & 9,9 & 8,7 & 11,9 & 13,9 & 11,1 & 12,3 & 13,8 & 13,2 & 11,9 & 9,6 & 14,1 & 11,1 & 11,9 & 13,5 & 12,2 \\
\hline VIIT-HQ & 8,1 & 6,8 & 8,4 & 9,8 & 9,9 & 9,2 & 9,9 & 8,5 & 11,0 & 9,9 & 10,4 & 7,9 & 8,2 & 8,9 & 8,8 \\
\hline $\begin{array}{l}\text { Indeks GL } \\
\text { HS 39 }\end{array}$ & 34,9 & 36,8 & 43,3 & 43,5 & 43,8 & 50,6 & 52,5 & 54,2 & 54,7 & 51,8 & 44,6 & 41,8 & 42,0 & 37,5 & 36,7 \\
\hline HIIT & 6,1 & 8,6 & 4,3 & 7,5 & 0,9 & 13,1 & 9,8 & 11,1 & 12,0 & 11,0 & 13,8 & 5,4 & 12,5 & 3,5 & 4,6 \\
\hline VIIT-LQ & 21,0 & 23,2 & 32,5 & 28,4 & 28,0 & 28,9 & 29,2 & 32,5 & 32,7 & 30,6 & 23,7 & 20,8 & 19,7 & 27,2 & 25,0 \\
\hline VIIT-HQ & 7,9 & 5,1 & 6,4 & 7,7 & 14,9 & 8,7 & 13,5 & 10,6 & 10,1 & 10,3 & 7,0 & 15,7 & 9,8 & 6,7 & 7,2 \\
\hline $\begin{array}{l}\text { Indeks GL } \\
\text { HS 84 }\end{array}$ & 27,2 & 37,5 & 32,6 & 33,2 & 32,2 & 26,6 & 29,9 & 29,0 & 26,2 & 34,9 & 36,6 & 35,3 & 36,8 & 38,0 & 34,5 \\
\hline HIIT & 1,3 & 2,0 & 2,0 & 4,8 & 6,7 & 3,7 & 4,9 & 0,9 & 3,9 & 6,6 & 6,5 & 7,7 & 11,3 & 3,2 & 3,2 \\
\hline VIIT-LQ & 21,2 & 26,6 & 24,6 & 23,8 & 21,2 & 17,4 & 17,1 & 23,1 & 12,7 & 16,9 & 18,0 & 15,0 & 14,4 & 20,0 & 17,1 \\
\hline VIIT-HQ & 4,5 & 8,9 & 5,9 & 4,5 & 4,3 & 5,3 & 7,8 & 5,1 & 9,5 & 11,3 & 12,1 & 12,5 & 11,0 & 14,7 & 14,1 \\
\hline $\begin{array}{l}\text { Indeks GL } \\
\text { HS 85 }\end{array}$ & 16,5 & 10,8 & 22,4 & 29,9 & 23,5 & 28,3 & 26,1 & 22,0 & 21,7 & 18,3 & 17,1 & 25,2 & 23,4 & 24,4 & 20,0 \\
\hline HIIT & 0,6 & 0,1 & 1,1 & 2,7 & 0,4 & 0,9 & 2,2 & 1,4 & 1,4 & 4,6 & 1,5 & 0,9 & 1,3 & 2,0 & 2,9 \\
\hline VIIT-LQ & 11,1 & 8,8 & 14,1 & 18,9 & 14,5 & 17,1 & 13,9 & 16,5 & 12,6 & 9,9 & 12,7 & 12,8 & 14,6 & 12,1 & 10,9 \\
\hline VIIT-HQ & 4,6 & 1,6 & 6,2 & 7,8 & 8,4 & 9,9 & 9,9 & 4,0 & 7,5 & 3,7 & 2,9 & 11,2 & 7,3 & 10,1 & 6,1 \\
\hline
\end{tabular}

Źródło: Opracowanie własne na podstawie http://www.trademap.org (dostęp 5.09.2016). 
Tabela 6. Intensywność i struktura polsko-fińskiego handlu wewnątrzgałęziowego w latach 2001-2015 (ogółem oraz wybrane działy HS)

\begin{tabular}{|c|c|c|c|c|c|c|c|c|c|c|c|c|c|c|c|}
\hline & 2001 & 2002 & 2003 & 2004 & 2005 & 2006 & 2007 & 2008 & 2009 & 2010 & 2011 & 2012 & 2013 & 2014 & 2015 \\
\hline $\begin{array}{l}\text { Indeks GL } \\
\text { ogółem }\end{array}$ & 9,9 & 8,9 & 9,4 & 15,4 & 13,3 & 14,6 & 11,7 & 13,5 & 13,6 & 12,9 & 13,9 & 13,9 & 13,0 & 18,6 & 18,2 \\
\hline HIIT & 0,9 & 1,3 & 0,4 & 1,1 & 1 , & 1,2 & 2,5 & 4,1 & U,0 & 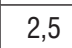 & 6 & 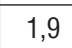 & 2 & 9 & 6 \\
\hline VIIT-LQ & 7,1 & 5,7 & 6,9 & 8, & 7,4 & 9,2 & 6,4 & 6,1 & 5,3 & 5,1 & 6,8 & 5,9 & 5,4 & 7,6 & 7,2 \\
\hline VIIT-HQ & 1,9 & 1,8 & 2,1 & 5 & 4,7 & 4,0 & 2 , & 3,2 & 4 & 5,2 & 4 & 6, & 4 & 8,1 & 7,4 \\
\hline $\begin{array}{l}\text { Indeks GL } \\
\text { HS } 72\end{array}$ & 6,8 & 5,3 & 4,8 & 7,7 & 17,1 & 20,4 & 16,7 & 20,2 & 7,3 & 2,2 & 3,2 & 2,9 & 1,6 & 3,3 & 2,5 \\
\hline HIIT & 0,0 & 0,0 & 0,5 & 1,9 & 4,4 & 1,3 & 2,0 & 2,0 & 1,5 & 0,3 & 0,2 & 1,2 & 0,5 & 0,5 & 0,6 \\
\hline VIIT-LQ & 6,3 & 4,9 & 3,9 & 4,1 & 10,3 & 15,1 & 12,2 & 14,0 & 1,7 & 0,8 & 1,8 & 0,8 & 0,4 & 0,5 & 0,2 \\
\hline VIIT-HQ & 0,5 & 0,3 & 0,4 & 1,7 & 2,4 & 4,0 & 2,6 & 4,2 & 4,2 & 1,1 & 1,2 & 1,0 & 0,8 & 2,4 & 1,7 \\
\hline $\begin{array}{l}\text { Indeks GL } \\
\text { HS } 84\end{array}$ & 13,2 & 13,5 & 23,0 & 20,0 & 21,8 & 19,8 & 24,1 & 19,8 & 20,5 & 19,3 & 28,4 & 24,6 & 26,4 & 27,7 & 29,3 \\
\hline HIIT & 0,2 & 1,4 & 1,2 & 1,5 & 0,7 & 0,1 & 1,6 & 0,5 & 2,3 & 2,2 & 4,2 & 3,5 & 2,6 & 2,2 & 2,0 \\
\hline VIIT-LQ & 12,2 & 10,8 & 16,8 & 15,3 & 14,2 & 15,4 & 17,7 & 13,6 & 10,9 & 11,3 & 14,4 & 11,9 & 17,8 & 16,6 & 18,4 \\
\hline VIIT-HQ & 0,8 & 1,2 & 5,0 & 3,1 & 6,9 & 4,2 & 4,6 & 5,6 & 7,2 & 5,7 & 9,7 & 9,2 & 6,0 & 8,8 & 8,8 \\
\hline $\begin{array}{l}\text { Indeks GL } \\
\text { HS } 85\end{array}$ & 6,1 & 6,3 & 5,7 & 8,0 & 6,9 & 16,3 & 7,2 & 8,2 & 12,3 & 16,3 & 17,0 & 24,3 & 22,6 & 20,4 & 20,9 \\
\hline HIIT & 0,1 & 0,1 & 0,0 & 0,2 & 0,1 & 0,3 & 1,8 & 0,1 & 0,5 & 1,5 & 0,2 & 2,3 & 0,3 & 0,7 & 1,5 \\
\hline VIIT-LQ & 5,5 & 5,3 & 5,2 & 3,7 & 5,7 & 12,4 & 4,1 & 5,8 & 8,5 & 3,1 & 12,5 & 14,4 & 8,9 & 8,1 & 11,0 \\
\hline VIIT-HQ & 0,5 & 0,7 & 0,5 & 3,9 & 0,8 & 3,0 & 1,2 & 2,1 & 3,4 & 11,7 & 4,1 & 7,5 & 13,3 & 11,4 & 8,3 \\
\hline
\end{tabular}

Źródło: Jak do tabeli 5.

Tabela 7. Intensywność i struktura polsko-norweskiego handlu wewnątrzgałęziowego w latach 2001-2015 (ogółem oraz wybrane działy HS)

\begin{tabular}{|l|r|r|r|r|r|r|r|r|r|r|r|r|r|r|r|}
\cline { 2 - 14 } \multicolumn{1}{l|}{} & 2001 & 2002 & 2003 & 2004 & 2005 & 2006 & 2007 & 2008 & 2009 & 2010 & 2011 & 2012 & 2013 & 2014 & 2015 \\
\hline $\begin{array}{l}\text { Indeks GL } \\
\text { ogótem }\end{array}$ & 12,5 & 11,9 & 61,2 & 39,5 & 46,7 & 35,2 & 21,6 & 32,8 & 37,3 & 25,9 & 22,4 & 29,0 & 36,6 & 25,5 & 26,9 \\
\hline HIIT & 1,5 & 0,3 & 0,7 & 2,2 & 19,0 & 11,3 & 0,8 & 8,2 & 0,5 & 2,6 & 4,4 & 6,2 & 3,9 & 5,4 & 2,2 \\
\hline VIIT-LQ & 5,7 & 7,0 & 14,5 & 30,5 & 14,0 & 12,1 & 10,3 & 14,8 & 18,7 & 14,4 & 9,2 & 12,6 & 19,4 & 12,3 & 10,4 \\
\hline VIIT-HQ & 5,4 & 4,6 & 46,0 & 6,8 & 13,6 & 10,6 & 10,6 & 9,8 & 18,0 & 8,8 & 8,7 & 10,1 & 13,2 & 7,8 & 14,3 \\
\hline $\begin{array}{l}\text { Indeks GL } \\
\text { HS 84 }\end{array}$ & 16,0 & 13,5 & 16,9 & 29,7 & 31,8 & 22,7 & 29,5 & 18,8 & 21,0 & 19,3 & 23,9 & 23,9 & 28,2 & 27,2 & 30,7 \\
\hline HIIT & 0,2 & 0,1 & 0,0 & 0,4 & 0,5 & 0,5 & 2,0 & 0,9 & 1,0 & 1,4 & 0,9 & 3,8 & 0,6 & 1,1 & 3,5 \\
\hline VIIT-LQ & 13,7 & 10,1 & 14,1 & 21,6 & 24,2 & 16,3 & 22,8 & 11,3 & 13,2 & 10,5 & 14,9 & 16,4 & 22,1 & 22,2 & 16,3 \\
\hline VIIT-HQ & 2,1 & 3,3 & 2,7 & 7,5 & 6,8 & 5,8 & 4,6 & 6,6 & 6,7 & 7,4 & 8,1 & 3,7 & 5,5 & 3,8 & 10,8 \\
\hline $\begin{array}{l}\text { Indeks GL } \\
\text { HS 89 }\end{array}$ & 26,3 & 16,7 & 91,8 & 67,6 & 79,8 & 68,0 & 43,7 & 83,8 & 75,6 & 69,1 & 48,1 & 72,5 & 77,8 & 61,4 & 66,9 \\
\hline HIIT & 4,5 & 0,0 & 0,0 & 0,0 & 56,2 & 43,9 & 0,0 & 58,6 & 0,0 & 17,1 & 22,8 & 41,8 & 17,4 & 34,4 & 0,1 \\
\hline VIIT-LQ & 3,0 & 8,2 & 1,1 & 63,8 & 2,2 & 0,1 & 4,0 & 13,2 & 26,8 & 24,4 & 1,0 & 2,2 & 27,5 & 0,3 & 3,2 \\
\hline VIIT-HQ & 18,8 & 8,5 & 90,7 & 3,9 & 21,3 & 24,0 & 39,6 & 12,1 & 48,9 & 27,6 & 24,3 & 28,5 & 33,0 & 26,7 & 63,6 \\
\hline
\end{tabular}

Źródło: Jak do tabeli 5. 
Tabela 8. Intensywność i struktura polsko-szwedzkiego handlu wewnątrzgałęziowego w latach 2001-2015 (ogółem oraz wybrane działy HS)

\begin{tabular}{|l|r|r|r|r|r|r|r|r|r|r|r|r|r|r|r|}
\cline { 2 - 14 } \multicolumn{1}{l|}{} & 2001 & 2002 & 2003 & 2004 & 2005 & 2006 & 2007 & 2008 & 2009 & 2010 & 2011 & 2012 & 2013 & 2014 & 2015 \\
\hline $\begin{array}{l}\text { Indeks GL } \\
\text { ogótem }\end{array}$ & 22,0 & 17,7 & 22,8 & 22,3 & 24,6 & 25,4 & 25,8 & 27,9 & 24,4 & 24,4 & 22,8 & 23,7 & 24,3 & 21,3 & 22,0 \\
\hline HIIT & 3,7 & 1,6 & 3,7 & 3,0 & 4,0 & 4,1 & 6,6 & 4,5 & 3,8 & 2,5 & 4,0 & 4,1 & 4,9 & 3,8 & 3,4 \\
\hline VIIT-LQ & 12,1 & 9,7 & 9,9 & 11,8 & 13,0 & 12,9 & 11,9 & 14,7 & 12,2 & 11,8 & 11,2 & 11,2 & 10,5 & 9,5 & 9,6 \\
\hline VIIT-HQ & 5,6 & 6,0 & 8,6 & 7,4 & 7,6 & 8,3 & 7,4 & 8,7 & 8,2 & 10,0 & 7,5 & 8,4 & 8,7 & 7,9 & 9,0 \\
\hline $\begin{array}{l}\text { Indeks GL } \\
\text { HS 84 }\end{array}$ & 18,6 & 19,7 & 21,7 & 21,3 & 23,6 & 25,1 & 23,6 & 22,2 & 18,0 & 20,7 & 23,4 & 25,1 & 28,6 & 26,7 & 23,6 \\
\hline HIIT & 1,8 & 0,2 & 3,1 & 1,3 & 2,1 & 2,1 & 2,3 & 3,1 & 2,2 & 1,0 & 1,0 & 1,8 & 3,8 & 3,6 & 2,9 \\
\hline VIIT-LQ & 14,3 & 15,2 & 15,4 & 16,1 & 17,5 & 18,1 & 18,3 & 15,1 & 11,2 & 14,5 & 17,6 & 16,8 & 16,1 & 15,9 & 11,9 \\
\hline VIIT-HQ & 2,4 & 4,3 & 3,3 & 3,9 & 3,9 & 4,7 & 3,0 & 4,0 & 4,6 & 5,2 & 4,8 & 6,4 & 8,6 & 7,3 & 8,8 \\
\hline $\begin{array}{l}\text { Indeks GL } \\
\text { HS 85 }\end{array}$ & 32,1 & 21,1 & 19,4 & 16,8 & 20,9 & 21,5 & 23,3 & 23,8 & 17,5 & 21,3 & 19,2 & 18,7 & 18,7 & 21,9 & 22,0 \\
\hline HIIT & 6,6 & 1,1 & 1,2 & 0,5 & 0,8 & 3,5 & 6,4 & 2,6 & 2,2 & 1,1 & 2,9 & 1,5 & 1,2 & 5,5 & 1,0 \\
\hline VIIT-LQ & 17,0 & 10,8 & 5,2 & 5,1 & 8,6 & 11,2 & 6,8 & 10,6 & 8,1 & 6,7 & 8,4 & 7,1 & 7,1 & 10,0 & 7,9 \\
\hline VIIT-HQ & 8,4 & 9,1 & 12,9 & 11,1 & 11,4 & 6,9 & 10,1 & 10,6 & 7,3 & 13,4 & 7,9 & 10,1 & 10,4 & 6,4 & 13,1 \\
\hline $\begin{array}{l}\text { Indeks GL } \\
\text { HS 87 }\end{array}$ & 27,7 & 29,5 & 22,5 & 30,7 & 29,9 & 27,8 & 27,6 & 35,1 & 33,2 & 26,0 & 25,3 & 29,8 & 27,4 & 24,4 & 25,5 \\
\hline HIIT & 2,9 & 0,8 & 2,8 & 3,8 & 4,9 & 0,8 & 10,7 & 2,5 & 1,6 & 0,5 & 4,6 & 1,6 & 1,8 & 1,7 & 4,2 \\
\hline VIIT-LQ & 15,5 & 12,7 & 6,3 & 18,5 & 15,3 & 16,5 & 11,2 & 19,1 & 16,0 & 11,8 & 7,0 & 11,1 & 9,8 & 6,6 & 6,7 \\
\hline VIIT-HQ & 9,3 & 16,0 & 13,4 & 8,4 & 9,8 & 10,6 & 5,8 & 13,5 & 15,6 & 13,7 & 13,7 & 17,2 & 15,8 & 16,1 & 14,5 \\
\hline
\end{tabular}

Źródło: Jak do tabeli 5.

\section{Zakończenie}

Z przeprowadzonej analizy nie wynikają wnioski wskazujące jednoznacznie, że ekspansja polskich firm na rynek skandynawski byłaby prostym rozwiązaniem. Istotnym wyzwaniem pozostaje z pewnością poziom oczekiwań konsumenckich, charakterystyczny dla społeczeństw wysoko rozwiniętych. Bez zewnętrznego wsparcia w postaci technologii oraz wiedzy na temat głębszych uwarunkowań procesu zakupowego wejście na te rynki wydaje się mocno ryzykowne.

Jeśliby natomiast spojrzeć na sektory dominujące $\mathrm{w}$ dwustronnej wymianie, w ramach których byłby potencjalnie możliwy transfer wiedzy i doświadczeń, wiele zależy od polityki inwestycyjnej koncernów skandynawskich prowadzących swoją działalność w Polsce oraz kształtujących się relacji dostawca-odbiorca w ramach korporacyjnych powiązań produkcyjnych. Analiza wymiany wewnątrzgałęziowej wskazuje niestety na fakt, że Polska wciąż jest traktowana jako tzw. tania lokalizacja 
(generalnie przewaga komponentu VIIT-LQ z pewnymi, nielicznymi obszarami wyższych kompetencji), co bezpośrednio wiąże się z zagrożeniem utrwalania problemów strukturalnych typowych dla pułapki średniego dochodu.

Podsumowując, rynki skandynawskie nie stanowią poważnej alternatywy dla Polski, jeśli chodzi o poszukiwanie kierunków dywersyfikujących strukturę handlu zagranicznego i ograniczających dominację wymiany z Niemcami. Z punktu widzenia geostrategicznych interesów na pewno jednak warto zachęcać zaawansowane technologicznie firmy skandynawskie do inwestowania w Polsce, bowiem ich obecność utrwala pozytywny wizerunek i wiarygodność jako partnera w polityce zagranicznej. Przekłada się ona, choć jak dotąd w ograniczonym zakresie, na możliwość pozyskania cennej wiedzy technologicznej oraz doświadczeń biznesowych kluczowych dla rozwijania własnych innowacyjnych przedsięwzięć.

\section{Literatura}

Ambroziak Ł., Wplyw bezpośrednich inwestycji zagranicznych na handel wewnątrzgałeziowy państw Grupy Wyszehradzkiej, Instytut Badań Rynku, Konsumpcji i Koniunktur, Warszawa 2013.

Balassa B., Trade Liberalisation and "Revealed" Comparative Advantage, „The Manchester School” Vol. 33, Issue 2, May 1965.

Brodzicki T., Śledziewska K., Determinanty wertykalnego i horyzontalnego handlu wewnątrzgałęiowego Polski. Analiza ekonometryczna, [w:] Handel międzynarodowy w rozwoju społeczno-ekonomicznym państw, red. S. Wydymus, M. Maciejewski, CeDeWu, Warszawa 2016.

Cieślik A., Wplyw przedsiębiorstw międzynarodowych na fragmentaryzacjęprodukcji i handel wewnatrzgałęziowy Polski z krajami OECD, „Gospodarka Narodowa” nr 10(206), 2008.

Cohn T.H., Global Political Economy. Theory and Practice, Routledge, New York 2016.

Czarny E., Śledziewska K., Międzynarodowa wspótpraca gospodarcza w warunkach kryzysu: wnioski dla Polski, PWE, Warszawa 2012.

Eichengreen B., Park D., Shin K., When Fast Growing Economies Slow Down: International Evidence and Implications for China, „NBER Working Paper” No. 16919, March 2011.

Gill I., Kharas H., An East Asian Renaissance: Ideas for Economic Growth, The World Bank, Washington, D.C. 2007.

Gill I., Kharas H., The Middle-Income Trap Turns Ten, „Policy Research Working Paper” No. 7403, The World Bank, Washington, D.C., August 2015. 
Greenaway D., Hine R., Milner C., Country Specific Factors and the Pattern of Horizontal and Vertical Intra-Industry Trade in the UK, „Weltwirtschaftliches Archiv” Vol. 130, No. 1, 1994.

Greenaway D., Hine R., Milner C., Vertical and Horizontal Intra-Industry Trade: A Cross-Industry Analysis for the United Kingdom, „The Economic Journal” Vol. 105, No. 433, 1995.

Grubel H., Lloyd P., Intra-Industry Trade. The Theory and Measurement of International Trade in Differentiated Products, Macmillan, London 1975.

http://unctadstat.unctad.org/UnctadStatMetadata/Classifications/Methodology\&Classifications.html

http://www.trademap.org

Księżopolski K., Bezpieczeństwo ekonomiczne, Dom Wydawniczy Elipsa, Warszawa 2011.

Malinowski K., Kultura bezpieczeństwa narodowego: koncepcja i możliwości zastosowania, [w:] Kultura bezpieczeństwa narodowego w Polsce i Niemczech, red. K. Malinowski, Instytut Zachodni, Poznań 2003.

Michalski B., Konsekwencje członkostwa w Unii Europejskiej dla polsko-niemieckiej wymiany handlowej dobrami mid-tech i high-tech, [w:] Jabłko niezgody. Regionalne wyzwania wspótczesnej gospodarki światowej, red. nauk. B. Drelich-Skulska, M. Domiter, W. Michalczyk, „Prace Naukowe Uniwersytetu Ekonomicznego we Wrocławiu” nr 407, Wydawnictwo Uniwersytetu Ekonomicznego, Wrocław 2015.

Michalski B., Polsko-niemiecka wymiana handlowa $w$ sektorze maszynowym $w$ latach 2001-2013. Ocena szans i zagrożeń, „Zeszyty Naukowe Uniwersytetu Szczecińskiego” nr 857, „Studia i Prace Wydziału Nauk Ekonomicznych i Zarządzania” nr 41, Wydawnictwo Naukowe Uniwersytetu Szczecińskiego, Szczecin 2015.

Michalski B., Umiędzynarodowienie sektora mid-tech na przykładzie wymiany handlowej sektora samochodowego w Polsce w latach 2004-2012, „Ekonomia Międzynarodowa” nr 6, 2014.

Ministerstwo Rozwoju, Plan na rzecz Odpowiedzialnego Rozwoju, https://www.mr.gov.pl/ media/14840/Plan_na_rzecz_Odpowiedzialnego_Rozwoju_prezentacja.pdf

Mińska-Struzik E., Od eksportu do innowacji. Uczenie się przez eksport polskich przedsiębiorstw, Difin, Warszawa 2014.

Molendowski E., Integracja handlowa w Nowych Państwach Członkowskich (UE-10). Doświadczenia $i$ wnioski dla innych krajów Europy Środkowej $i$ Wschodniej, Difin, Warszawa 2012.

Ohno K., Avoiding the Middle-Income Trap Renovating Industrial Policy Formulation in Vietnam, „ASEAN Economic Bulletin” Vol. 26, No. 1, April 2009.

Paus E., Confronting the Middle Income Trap: Insights from Small Latecomers, „Studies in Comparative International Development” Vol. 47, Issue 2, June 2012.

Polska jako peryferie, red. T. Zarycki, Scholar, Warszawa 2016. 
Raczkowski K., Percepcja bezpieczeństwa ekonomicznego i wyzwania dla zarzadzania nim w XXI wieku, [w:] Bezpieczeństwo ekonomiczne. Wyzwania dla zarządzania państwem, red. K. Raczkowski, Oficyna a Wolter Kluwers business, Warszawa 2012.

Radło J.M., Ciesielska D., Polska w pułapce średniego dochodu? Perspektywy konkurencyjności polskiej gospodarki i regionów, Difin, Warszawa 2013.

Smith R., El-Anis I., Farrands C., International Political Economy in the $21^{\text {st }}$ Century. Contemporary Issues and Analyses, Routledge, New York 2013.

Staniszkis J., Podwójna peryferyjność Polski, http://www.nowakonfederacja.pl/podwojna-peryferyjnosc-polski/ Staniszkis, J., Polska bieda, „Do Rzeczy” nr 19/170, 9-15 maja 2016.

Wiśniewski R., Kultura strategiczna, czyli o kulturowych uwarunkowaniach polityki zagranicznej i bezpieczeństwa, „Przegląd Strategiczny” nr 1, 2012.

Wójcik P., Mit Wyszehradu. Niedoceniony Bałtyk, „Dziennik Gazeta Prawna” nr 92/4239, 13-15 maja 2016.

\section{Looking for Diversification: The Current State and Prospects of the Polish-Scandinavian Trade Development}

The paper aims at analysing the characteristics of the Polish-Scandinavian trade and at evaluating prospects of its further development in the context of the growing diversification of Polish exporting markets. The motivation behind this issue is rooted in the high dependence of the Polish economy on the German market. This brings about a threat to economic security through a specific technological dependence, which may result in a lot of challenges characteristic for the middle-income trap. This problem can be explained by the thesis of the blight of German proximity. The features of intensive trade relations, mostly in the motor vehicle industry and machinery (to some extent also in the electronic and electrical sector), require finding convenient locations for subsidiaries and further suppliers within corporate added-value chains. It should help exploiting current cost and efficiency advantages of host economies and thus block the development of potential innovative alternatives induced by the too weak domestic support.

For this reason, it is justified to intensify trade relations with other countries whose markets may be attractive for Polish exporters. They should also have competencies and advantages which are insufficient in the Polish economy. Hence, this transfer of knowledge through the trade cooperation (the concept of learning by exporting) may have an impact on the national innovation system. Choosing Scandinavian countries is coherent with the attempts to diversify the structure of 
exporting markets and is one of the critical dimensions of enhanced cooperation in the region of the Baltic Sea.

The research on the trade relations covers the period 2001-2015 together with the original insight into the prospects for their further development. For this purpose, the trade data of the International Trade Centre were used. Their disaggregation (2-, 4- and 6-digit) within the Harmonised System made possible the identification of the most important sectors, product clusters and even specific commodities which may be Polish exporting hits. Another dimension of the analysis covers the technological intensity of the Polish exports and imports with Scandinavian countries, the structure of Polish trade balance and the intensity of the intra-industry trade (Grubel-Lloyd index) together with its subcategories (horizontal, vertical-low quality, vertical-high quality) in the chapters with the highest share in bilateral trade.

Keywords: Poland, foreign trade, middle-income trap, Scandinavian countries, economic security.

\section{A la recherche de diversification. État et perspectives de développement de l'échange commercial scandinavo-polonais}

L'objet de ce texte est l'échange commercial scandinavo-polonais ainsi que l'évaluation des perspectives de son développement dans le contexte de la diversification progressive des marchés d'exportation polonais. La pertinence de cette problématique résulte d'une forte dépendance de la Pologne dans les contacts commerciaux et d'investissement intensifs avec l'Allemagne. En effet, ils prennent la forme d'une colonisation corporative réalisée par un partenaire plus fort.

La conséquence de cet état de choses est une menace à la sécurité économique sous forme de dépendance technologique et, plus précisément, de défis caractéristiques de piège du revenu intermédiaire (en anglais middle-income trap). D’après l'auteur, l'explication de sa spécificité en Europe centrale peut être basée sur la thèse d'une malédiction de la proximité allemande. La caractéristique des relations commerciales intensives, en particulier dans le secteur automobile et des machines (dans une certaine mesure également dans le secteur des équipements électriques et électroniques) exige une disposition des entreprises de sous-traitance dans le cadre des chaînes corporatives de la création de valeur ajoutée. Cela aboutit à exploiter dans la mesure maximale les avantages de coût et d'efficacité des pays d'accueil et donc bloquer réellement la possibilité de développer des alternatives sous la forme de projets innovants nationaux. 
C'est pour cette raison qu'il est justifié d'intensifier de nouvelles orientations de coopération avec les pays attrayants pour les exportateurs polonais et disposant des avantages de compétences qui manquent dans l'économie polonaise. Ainsi, le transfert des connaissances à travers la coopération commerciale peut constituer un coup de pouce pour le système national d'innovation. Le choix des pays nordiques (Danemark, Finlande, Norvège, Suède) s'inscrit bien dans la diversification d'échange commercial et constitue une des dimensions essentielles du renforcement des relations proposé dans la région de la mer Baltique.

Le diagnostic de la coopération précédente (années 2001-2015) ainsi que l'évaluation des perspectives de son développement effectuée par l'auteur reposent sur les données recueillies par le Centre du Commerce International qui concernent l'échange commercial de la Pologne avec le Danemark, la Finlande, la Norvège et la Suède. La désagrégation pertinente de ces données (selon le niveau de détail à deux, quatre et six chiffres) dans le cadre du Système Harmonisé a permis d'identifier les secteurs et les groupes de produits les plus importants ainsi que les biens concrets constituant un succès pour les exportations polonaises.

Cette analyse porte également sur l'avancement technologique des exportations et des importations polonaises, la structure de la balance commerciale et l'intensité du commerce intra-branche (basée sur l'indice de Grubel-Lloyd) avec ses souscatégories (échange horizontal, qualité verticale basse, qualité verticale haute) dans les unités cruciales pour les relations commerciales bilatérales.

Mots-clés: Pologne, commerce extérieur, piège du revenu intermédiaire, pays scandinaves, sécurité économique.

\section{В поисках диверсификации. Современное состояние и перспективы развития польско-скандинавской торговли.}

Цель статьи состоит в анализе характеристики польско-скандинавской торговли и оценке перспектив ее дальнейшего развития в контексте растущей диверсификации польских экспортных рынков. Важность этого вопроса вытекает из высокой зависимости польской экономики от немецкого рынка, которая принимает форму корпоративного неоколониализма.

Это угрожает экономической безопасности, особенно в виде технологической зависимости, что может привести к проблемам, характерным для ловушки среднего дохода. Ее специфику в Центральной Европе, по мнению автора, можно объяснить, используя тезис о проклятии немецкой географической близости. Характеристика интенсивных торговых отношений, 
прежде всего в автомобильной промышленности и машиностроении (и в некоторой степени также в электрическом и электронном секторах), требует такого распределения компаний-поставщиков в рамках цепочек создания добавленной стоимости, чтобы максимально использовать преимущества, связанные с ценами и эффективностью, принимающих стран и, таким образом, реально блокировать возможность разработки альтернатив в виде национальных инновационных проектов.

Поэтому оправданной является интенсификация торговых отношений со странами, у которых привлекательный рынок с точки зрения польских экспортеров, и обладающих отсутствующими в польской экономике преимуществами. Таким образом, передача знаний через торгово-экономическое сотрудничество может стать стимулом для национальной инновационной системы. Выбор стран Северной Европы (Дания, Финляндия, Норвегия, Швеция) хорошо вписывается в эту схему и является одним из важнейших аспектов предлагаемого укрепления отношений в регионе Балтийского моря.

Исследование торговых отношений охватывает период 2001-2015 гг. и включает оценку перспектив их дальнейшего развития. В работе использовались данные Центра Международной Торговли. Их дезагрегация (на уровне 2, 4 и 6 знаков) в рамках Гармонизированной системы сделала возможным определить наиболее важные секторы, кластеры продуктов и даже конкретные товары, которые могут стать хитами польского экспорта. Анализ охватывает также технологическую интенсивность польского экспорта и импорта в отношении скандинавских стран, структуру польского торгового баланса и интенсивность внутриотраслевой торговли (Индекс Грубеля-Ллойда), указывая подкатегории (обмен по горизонтали, по вертикали - низкое качество, по вертикали - высокое качество) в областях, которые являются самыми важными в двусторонней торговле.

Ключевые слова: Польша, внешняя торговля, ловушка среднего дохода, скандинавские страны, экономическая безопасность. 